\title{
PERBANDINGAN HIDROLISIS ENZIMATIS DAN ASAM TERHADAP PATI JAGUNG MANIS (Zea mays L.) DALAM PEMBUATAN GULA CAIR
}

\author{
RTM Sutamihardja ${ }^{1)}$, Mia Azizah ${ }^{2 *}$, Bekti Dwisepti Mafiana ${ }^{1)}$ \\ ${ }^{1)}$ Program Studi Kimia FMIPA Universitas Nusa Bangsa Bogor \\ ${ }^{2}$ Program Studi Biologi FMIPA Universitas Nusa Bangsa Bogor \\ Jl. KH Sholeh Iskandar KM 4 Cimanggu Tanah Sareal, Bogor 16166 \\ *email : miaazizah23@gmail.com
}

\section{ABSTRACT \\ Comparison Hydrolisis of Enzymatic and Acid of Sweet Corn Starch (Zea mays L.) in Liquid Sugar Production}

\begin{abstract}
Sweet corn starch (Zea mays L.) contains high carbohydrate that can be used for food and industrial purposes. Sweet corn starch can be used for liquid sugar as alternative sweetener by enzymatic or acid hydrolysis. The enzymatic hydrolysis was performed by treating the starch with alpha amylase for liquefaction and glucoamylase for saccharification, while acid hydrolysis was performed by mixing the starch with 1,0 $N$ hydrochloric acid. According to the results, the yield of enzymatic hydrolysis is higher than acid hydrolysis. The highest yield of liquid sugar is $91,73 \%$ produced by enzymatic hydrolysis using alpha amylase $42 \mu \mathrm{L}$ and glucoamylase $42 \mu \mathrm{L}$ and $59,40 \%$ of reducing sugar. The yield of liquid sugar produced by acid hydrolysis using $\mathrm{HCl} \mathrm{1,0} \mathrm{N}$ is 78,55\% and 31,48\% of reducing sugar.
\end{abstract}

Key words : $\quad$ Zea mays, starch, liquid sugar, hydrolisis of hydrochloric acid, hydrolisis of alpha amylase, hydrolisis of glucoamylase

\begin{abstract}
ABSTRAK
Pati jagung manis (Zea mays L.) mengandung karbohidrat cukup tinggi yang dapat dimanfaatkan untuk bahan pangan dan industri. Pati jagung manis dapat diolah menjadi gula cair dan digunakan sebagai pemanis alternatif melalui hidrolisis pati baik secara enzimatis atau asam. Hidrolisis enzimatis melalui tahap likuifikasi menggunakan alfa amilase dan tahap sakarifikasi menggunakan glukoamilase. Hidrolisis asam dilakukan menggunakan asam klorida $0,1 \mathrm{~N}$. Hasil penelitian menunjukkan bahwa gula cair hasil hidrolisis enzimatis menghasilkan rendemen lebih tinggi dibandingkan hidrolisis asam. Rendemen gula cair paling tinggi dihasilkan pada proses hidrolisis enzimatis menggunakan alfa amilase $42 \mu \mathrm{L}$ dan glukoamilase $42 \mu \mathrm{L}$ sebesar $91,73 \%$ dengan nilai gula pereduksi sebesar 59,40\%. Rendemen gula cair hidrolisis asam menggunakan $\mathrm{HCl} 1,0 \mathrm{~N}$ sebesar 78,55\% dengan nilai gula pereduksi sebesar $31,48 \%$.
\end{abstract}

Kata kunci : Zea mays, pati, gula cair, hidrolisis $\mathrm{HCl}$, hidrolisis enzim alfa-amilase, hidrolisis enzim glukoamilase

\section{PENDAHULUAN}

Gula tebu merupakan salah satu kebutuhan pokok masyarakat Indonesia. Peran utamanya sebagai pemanis. Kebutuhan gula tebu sebagai bahan pemanis makanan maupun minuman semakin meningkat setiap tahunnya. Menurut Badan Pusat Statistik, pada tahun 2011 Indonesia mengimpor sebanyak 2.371.250 ton gula tebu. Tahun 2012 angka impor gula tebu naik menjadi 2.743 .778 ton, dan di tahun 2013 kenaikan semakin meningkat menjadi 3.343.803 ton.
Kekurangan bahan pemanis alam (gula tebu) mendorong masyarakat untuk mengkonsumsi gula sintetis (buatan) seperti sakarin (biang gula) dan natrium siklamat (bibit gula). Akan tetapi, bahan pemanis buatan tidak bisa sepenuhnya menggantikan bahan pemanis alam karena kadar penggunaannya dibatasi oleh peraturan kesehatan di banyak Negara termasuk di Indonesia, yaitu sesuai dengan Peraturan Menteri Kesehatan Republik Indonesia No. 722/MENKES/PER/IX/1988 tentang Bahan Tambahan Makanan.

Bahan pemanis lain selain gula tebu atau sukrosa (gula yang kita kenal sehari- 
hari) perlu dikembangkan untuk mengatasi masalah tersebut. Pemanis lain tersebut yaitu gula cair. Gula cair diperoleh dari hasil hidrolisis pati. Pati yang diolah bisa dari pati sagu, padi, jagung, umbi-umbian (talas, ubi jalar, kimpul, singkong). Contoh gula cair dari hasil hidrolisis pati yaitu glukosa, fruktosa, maupun maltosa (Mahreni dan Sulistyowati, 2004).

Gula cair dapat diperoleh dari pati dengan cara hidrolisis dengan katalis asam atau katalis enzim. Pada penelitian Fitriana (2016), gula cair dihasilkan dari hidrolisis pati jagung secara asam. Namun, menurut Triyono (2009) pembuatan gula cair dari hidrolisis pati secara enzimatis dapat menghasilkan rendemen dan mutu gula cair yang lebih tinggi jika dibandingkan dengan cara hidrolisis asam. Oleh karena itu, maka perlu dilakukan penelitian perbandingan hidrolisis enzimatis dan asam dalam pembuatan gula cair serta perlakuan variasi konsentrasi enzim alfa amilase dan glukoamilase dalam pembuatan gula cair secara enzimatis untuk membuktikan apakah hasil rendemen gula cair secara enzimatis lebih banyak dibandingkan dengan hidrolisis asam.

Bahan baku utama yang digunakan adalah jagung. Berdasarkan data dari Badan Pusat Statistik (2015), produksi jagung di tahun 2015 sebanyak 20,67 juta ton atau mengalami kenaikan sebanyak 1,66 juta ton $(8,72 \%)$ dibandingkan tahun 2014. Peningkatan produksi terjadi karena kenaikan luas area panen seluas 160,48 ribu hektar $(4,18 \%)$ dan kenaikan produktivitas sebesar 2,16 kuintal/hektar (4,36\%).

\section{BAHAN DAN METODE}

\section{Bahan dan Alat}

Bahan yang digunakan yaitu: Jagung manis, air suling, alfa amilase dari Sigma (aktivitas enzim 20000-60000 U/mL), glukoamilase dari Sigma, $\mathrm{HCl}, \mathrm{NaOH}$, $\mathrm{Na}_{2} \mathrm{CO}_{3}$, arang aktif dari tempurung kelapa, resin kation anion, $\mathrm{NaOH}, \mathrm{HCl}, \mathrm{H}_{2} \mathrm{SO}_{4}$, heksana, larutan Luff schoorl, KI 20\%, lugol, indikator BCG:MM, asam borat, $\mathrm{Pb}$ asetat $5 \%, \quad\left(\mathrm{NH}_{4}\right)_{2} \mathrm{HPO}_{4} \quad 10 \%, \quad \mathrm{Na}_{2} \mathrm{~S}_{2} \mathrm{O}_{3}$ $0,1 \mathrm{~N}$, kanji.

Peralatan yang digunakan adalah wadah penampung tepung, kain saring, loyang, oven, blender, mikro pipet, autoclave, spatula, termometer, pemanas listrik, neraca analitik, penangas air, kolom, botol timbang, cawan porselen, oven, tanur, desikator, labu ukur, pipet volumetri, corong, tabung reaksi, alat soxhlet, $\mathrm{pH}$ meter, buret, gelas ukur, kertas lakmus, pendingin tegak, alat destilasi, pemanas listrik.

\section{Metode}

\section{Pembuatan Pati dari Jagung Manis}

Proses pembuatan pati dari jagung manis dimulai dengan cara memisahkan biji jagung dari tongkolnya dan membersihkannya, kemudian jagung yang sudah bersih ditambah air lalu diblender (5:2). Larutan hasil pemblenderan diperas dan disaring dengan kain saring. Proses berikutnya dari hasil penyaringan didiamkan selama 24 jam untuk mengendapkan patinya, selanjutnya air pada bagian atas dibuang sedangkan endapan pati dicuci dengan air dan diendapkan lagi beberapa saat. Pati yang diperoleh selanjutnya dikeringkan dengan sinar matahari, setelah itu dilanjutkan pengeringan dengan menggunakan oven pada suhu 800C (Risnoyatiningsih, 2011)

\section{Pembuatan Gula Cair}

Pembuatan gula cair dilakukan menggunakan dua metode hidrolisis. Metode pertama yaitu pembuatan gula cair secara hidrolisis enzimatis dengan variasi volume alfa amilase dan glukoamilase. Metode kedua yaitu pembuatan gula cair secara hidrolisis asam menggunakan $\mathrm{HCl}$ $1,0 \mathrm{~N}$.

\section{a. Hidrolisis Enzimatis}

Pembuatan gula cair secara hidrolisis enzimatis terdiri atas dua tahap. Pertama adalah tahap likuifikasi. Pati jagung manis ditimbang sebanyak 30 gram lalu dilarutkan dalam $200 \mathrm{~mL}$ air dan diaduk rata, $\mathrm{pH}$ 
diatur 5-7. Sampel dipanaskan pada suhu $90^{\circ} \mathrm{C}$ dan ditambahkan enzim alfa amilase (1; 1,2 dan $1,4 \mathrm{~mL} / \mathrm{kg}$ pati) yang setara dengan $(30 ; 36$ dan $42 \mu \mathrm{L})$ sambil diaduk rata. Proses ini berlangsung selama 60 menit. Setelah itu dianalisis kadar gula pereduksinya.

Hasil optimum likuifikasi diteruskan ke tahap sakarifikasi. Sampel didinginkan sampai $60^{\circ} \mathrm{C}, \mathrm{pH}$ diatur 4-4,6 lalu ditambahkan enzim glukoamilase $(1 ; 1,2$ dan $1,4 \mathrm{~mL} / \mathrm{kg}$ pati) yang setara dengan (30; 36 dan $42 \mu \mathrm{L}$ ). Proses ini berlangsung selama 72 jam.

Gula cair dinetralkan menggunakan $\mathrm{Na}_{2} \mathrm{CO}_{3}$ dan ditambahkan 0,5 gram arang akif lalu dipanaskan pada suhu $80^{\circ} \mathrm{C}$ dan pengadukan selama 30 menit. Larutan didiamkan selama 1 jam dan disaring. Setelah itu larutan dialirkan ke dalam kolom resin ion lalu sampel diuapkan pada suhu $60^{\circ} \mathrm{C}$.

\section{b. Hidrolisis Asam}

Pembuatan gula cair secara hidrolisis asam tediri atas dua tahap yaitu tahap gelatinisasi dan hidrolisis. Pati jagung manis ditimbang sebanyak 30 gram ke dalam erlenmeyer lalu ditambahkan air panas sebanyak $200 \mathrm{~mL}$. Setelah itu sampel dipanaskan di atas penangas dengan suhu $60-70^{\circ} \mathrm{C}$ hingga terbentuk gel. Sampel kemudian ditambahkan $\mathrm{HCl} \quad 1,0 \quad \mathrm{~N}$ sebanyak $30 \mathrm{~mL}$, lalu dimasukkan ke dalam autoclave pada suhu $121^{\circ} \mathrm{C}$ selama 90 menit.

Gula cair dinetralkan menggunakan $\mathrm{Na}_{2} \mathrm{CO}_{3}$ dan ditambahkan 0,5 gram arang akif lalu dipanaskan pada suhu $80^{\circ} \mathrm{C}$ dan pengadukan selama 30 menit. Larutan didiamkan selama 1 jam dan disaring. Setelah itu larutan dialirkan ke dalam kolom resin ion lalu sampel diuapkan pada suhu $90^{\circ} \mathrm{C}$.

\section{Analisis Hasil : Uji Fisik}

Parameter fisik yang dianalisis meliputi rasa, bau, warna dan nilai rendemen. Untuk analisis bau, rasa dan warna menggunakan indra penciuman, pengecap dan penglihatan. Nilai rendemen gula cair dihitung menggunakan rumus :

Rendemen $(\%)=$

$$
\frac{\mathrm{Bs} \times\left(\frac{\mathrm{Bk}}{100}\right)}{\mathrm{Bp} \times\left(1-\frac{\mathrm{Ka}}{100}\right)} \times 100 \%
$$

Keterangan:

$$
\begin{array}{ll}
\mathrm{Bs} & \text { : berat gula cair } \\
\mathrm{Bk} & \text { : total padatan gula cair } \\
\mathrm{Bp} & \text { : berat pati yang digunakan } \\
\mathrm{Ka} & \text { : kadar air pati }
\end{array}
$$

\section{Analisis Hasil : Uji Kimia}

Analisis kadar air, abu, lemak, protein dan karbohidrat menggunakan SNI 012891-1992.

\section{Kadar Gula Pereduksi Metode Luff Schoorl}

Sampel ditimbang sebanyak 2 gram dan dimasukkan ke dalam labu ukur 250 $\mathrm{mL}$ lalu ditambahkan $50 \mathrm{~mL}$ air suling, 5 $\mathrm{mL} \mathrm{Pb}$ asetat $5 \%$ dan 1 tetes $\left(\mathrm{NH}_{4}\right)_{2} \mathrm{HPO}_{4}$ 10\%. Apabila timbul endapan putih, maka penambahan $\mathrm{Pb}$ asetat sudah cukup. Larutan sampel ditambahkan $15 \mathrm{~mL}$ $\left(\mathrm{NH}_{4}\right)_{2} \mathrm{HPO}_{4} 10 \%$. Larutan ditambahkan air suling sampai tanda batas tera. Larutan dikocok, didiamkan selama 30 menit dan disaring. Hasil saringan dipipet $10 \mathrm{~mL}$ ke erlenmeyer lalu ditambahkan $15 \mathrm{~mL}$ air suling dan $25 \mathrm{~mL}$ Luff Schoorl serta beberapa butir batu didih. Erlenmeyer dihubungkan dengan pendingin tegak lalu dipanaskan di atas penangas listrik dan dididihkan selama 10 menit kemudian diangkat dan didinginkan. Setelah dingin, larutan ditambahkan $10 \mathrm{~mL}$ KI $20 \%$ dan 25 $\mathrm{mL} \quad \mathrm{H}_{2} \mathrm{SO}_{4} \quad 25 \%$. Larutan dititar menggunakan $\mathrm{Na}_{2} \mathrm{~S}_{2} \mathrm{O}_{3} \quad 0,1 \quad \mathrm{~N}$ dengan indikator kanji $0,5 \%$. Penetapan blanko dilakukan dengan $25 \mathrm{~mL}$ air dan $25 \mathrm{~mL}$ Luff Schoorl seperti cara sebelumnya.

$$
\text { V koreksi }=\frac{\text { V blanko }-\mathrm{V} \text { sampel }}{0,1} \times \mathrm{N} \text { tio }
$$




$$
\mathrm{W} 1=\underset{\left(\left(\mathrm{V}_{\text {koreksi }}-\mathrm{V}_{\text {tio tabel Luff Schoorl }}\right) \times \text { selisih }\right)}{\operatorname{mg} \text { tabel }}
$$

Gula reduksi $(\%)=\frac{W 1 \times f p}{W} \times 100 \%$

Keterangan:

$$
\begin{array}{ll}
\text { W1 } & \text { : mg setara tabel Luff School } \\
\mathrm{fp} & \text { : faktor pengenceran } \\
\mathrm{W} & \text { : bobot sampel }(\mathrm{mg})
\end{array}
$$

\section{Analisis Kandungan Pati Kualitatif}

Sampel gula cair dipipet sebanyak 510 tetes ke dalam tabung reaksi lalu ditambahkan sedikit air untuk memudahkan pengamatan. Sampel ditambahkan 2 tetes larutan lugol ke dalam tabung reaksi. Perubahan warna diamati. Apabila warna berubah menjadi biru atau ungu, maka dalam sampel positif mengandung pati.

\section{HASIL DAN PEMBAHASAN}

Jagung manis yang dideterminasi adalah jagung manis yang berumur 3,5 bulan dan berasal dari daerah Lampung. Hasil determinasi tanaman jagung manis didapatkan hasil berupa jagung manis berjenis Zea mays L., suku Poaceae.
Komposisi utama jagung manis adalah pati, yaitu sekitar $70 \%$ dari bobot biji (Prambudi, 2008). Bahan utama pembuatan gula cair dari jagung manis adalah pati jagung manis. Jagung manis yang digunakan sekitar $6,25 \mathrm{~kg}$. Jagung manis dikupas dan dibersihkan dengan tujuan untuk menghilangkan rambutrambut halus yang menempel pada bijinya. Jagung manis diblender untuk diambil sarinya. Biji jagung manis sebanyak 6,25 $\mathrm{kg}$ menghasilkan tepung pati sebanyak 1,21 $\mathrm{kg}$ atau sebanyak $19,36 \%$.

Pati jagung manis yang telah dibuat lalu dilakukan uji proksimat. Uji proksimat ini bertujuan untuk mengetahui kualitas dari pati yang digunakan untuk proses hidrolisis menjadi gula cair. Hasil dari uji proksimat pati jagung manis dapat dilihat pada Tabel 1.

Kandungan gula pereduksi menentukan kualitas gula cair yang dihasilkan dari proses hidrolisis pati. Penentuan kadar gula pereduksi pada proses hidrolisis enzimatis dilakukan pada tahap likuifikasi dan sakarifikasi. Tahap likuifikasi dilakukan dengan variasi volume alfa amilase (30; 36 dan $42 \mu \mathrm{L})$. Hasil kadar gula pereduksi tahap likuifikasi dapat dilihat pada Gambar 1.

Tabel 1. Kandungan Proksimat Pati Jagung Manis

$\begin{array}{cccc}\text { Parameter } & \begin{array}{c}\text { Pati Jagung } \\ \text { Manis }\end{array} & \begin{array}{c}\text { Pati Jagung Manis } \\ \text { (Fitriana, 2016) }\end{array} & \text { SNI Tepung Jagung }\end{array}$

\begin{tabular}{lccc}
\hline Air $(\%)$ & 3,94 & 8,28 & $\leq 10,00$ \\
Abu $(\%)$ & 1.12 & 0,86 & $\leq 1,00$ \\
Protein $(\%)$ & 9,46 & 8,70 & - \\
Lemak $(\%)$ & 1,18 & 1,07 & - \\
Karbohidrat(\%) & 63,89 & - & - \\
\hline
\end{tabular}




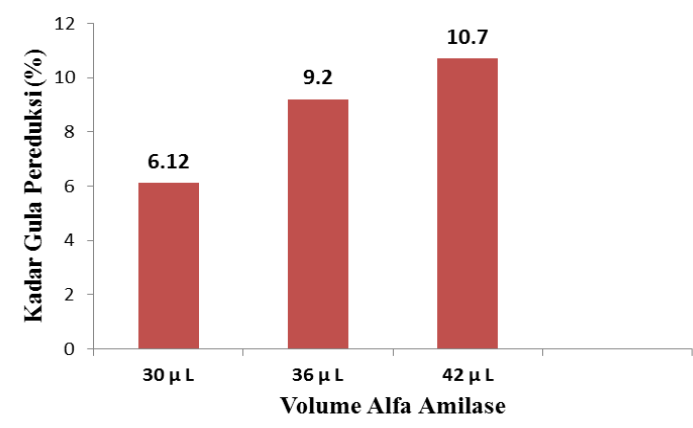

Gambar 1. Gula Pereduksi Likuifikasi

Berdasarkan Gambar 1, kadar gula pereduksi tertinggi pada tahap likuifikasi sebesar $10,7 \%$ pada volume enzim alfaamilase $42 \mu \mathrm{L}$. Semakin besar volume enzim yang ditambahkan, maka akan semakin besar kadar gula pereduksi yang dihasilkan dan masih ada kemungkinan kadar gula pereduksi naik apabila volume enzim ditingkatkan atau akan berubah konstan pada batas-batas volume tertentu (Rahmawati et al., 2015). Hasil tahap likuifikasi dengan enzim alfa-amilase menunjukkan bahwa kadar gula pereduksi masih rendah. Kadar gula pereduksi pada tahap likuifikasi belum dapat dibandingkan dengan kadar gula pereduksi pada SNI, karena pada tahap likuifikasi pati belum terhidrolisis sempurna menjadi glukosa. Rendahnya kadar gula pereduksi ini disebabkan enzim alfa-amilase ini memecah ikatan $\alpha-(1,4)$ glikosidik pada substrat dan menghasilkan gula reduksi dan dekstrin dengan glukosa dalam jumlah kecil (Rahmawati et al., 2015). Berdasarkan reaksi tesebut, kemudian dilanjutkan tahap sakarifikasi dengan menjadikan volume enzim alfa-amilase $42 \mu \mathrm{L}$ sebagai volume untuk menghidrolisis pati menjadi gula cair yang paling baik dalam tahap likuifikasi.

Tahap sakarifikasi dilakukan menggunakan enzim glukoamilase dengan variasi volume glukoamilase (30; 36 dan 42 $\mu \mathrm{L})$. Hasil kadar gula pereduksi tahap sakarifikasi dapat dilihat pada Gambar 2.

Kadar gula pereduksi tertinggi pada tahap sakarifikasi sebesar 59,40\% pada volume enzim glukoamilase $42 \mu \mathrm{L}$. Hasil tahap sakarifikasi (Gambar 2) menunjukkan terjadi peningkatan kadar gula pereduksi, jika dibandingkan dengan hasil kadar gula pereduksi pada tahap likuifikasi (Gambar 1). Adanya peningkatan kadar gula pereduksi ini disebabkan pada saat likuifikasi pati diubah menjadi maltosa, dekstrin dan glukosa oleh alfa-amilase. Pada saat tahap sakarifikasi terjadi proses hidrolisis maltosa dan dekstrin menjadi glukosa oleh enzim glukoamilase yang tidak hanya mampu memutuskan ikatan $\alpha$ $(1,4)$ glikosidik tetapi juga mampu menghidrolisis ikatan $\alpha-(1,6)$ glikosidik, sehingga proses hidrolisis berlangsung maksimal (Risnoyatiningsih, 2011).

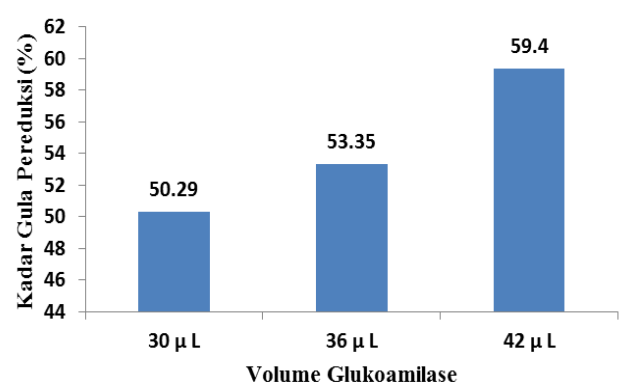

Gambar 2. Gula Pereduksi Sakarifikasi

Gula cair dapat dibuat melalui hidrolisis pati secara enzimatis atau asam. Asam yang digunakan adalah $\mathrm{HCl}$ dengan konsentrasi 1,0 N (Fitriana, 2016). Kadar gula pereduksi hasil hidrolisis enzimatis dibandingkan dengan gula cair asam dan hasilnya dapat dilihat pada Gambar 3.

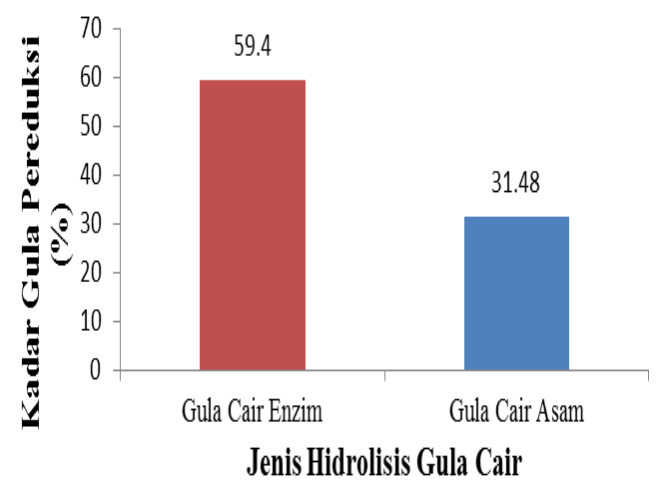

Gambar 3. Gula Pereduksi Sampel 
Kadar gula pereduksi gula cair secara enzimatis yaitu sebesar 59,40 \% lebih besar bila dibandingkan dengan kadar gula pereduksi gula cair secara asam yaitu sebesar 31,48\%. Jika dibandingkan dengan kadar gula pereduksi SNI, kedua kadar gula pereduksi tersebut masih memenuhi standar, batas terendah nilai gula pereduksi SNI sebesar $30 \%$. Kadar gula pereduksi enzimatis lebih besar bila dibandingkan dengan kadar gula pereduksi asam, hal ini disebabkan enzim bekerja spesifik. Enzim alfa-amilase bekerja memutus ikatan $\alpha$ $(1,4)$ glikosidik, dan enzim glukoamilase memecah ikatan $\alpha-(1,4)$ glikosidik dan $\alpha$ $(1,6)$ glikosidik pada pati. Sedangkan pada hidrolisis pati secara asam, pati akan dipecah secara acak (Mahmudatussaadah, 2014).

Pati jagung manis dihidrolisis menggunakan enzim dan asam menjadi gula cair. Parameter fisik gula cair yang diuji adalah rasa, bau, warna dan rendemen. Hasil uji fisik gula cair dapat dilihat pada Tabel 2.

Berdasarkan Tabel 2, gula cair hasil hidrolisis pati secara enzimatis dan asam memiliki rasa manis dan memenuhi persyaratan SNI 01-2978-1992. Untuk parameter bau dan warna belum memenuhi persyaratan. Sampel gula cair memiliki bau yang khas yaitu bau jagung manis yang berasal dari bahan baku yang digunakan yaitu jagung manis. Gula cair hasil hidrolisis enzimatis dan asam berwarna kuning. Hal ini disebabkan karena adanya proses pencoklatan.

Pati jagung manis yang telah dihidrolisis akan menghasilkan gula cair. Banyaknya jumlah gula cair dari hasil hidrolisis dapat diketahui dengan menghitung rendemen yang dihasilkan.

Pada uji ini, gula cair dibuat melalui hidrolisis enzimatis menggunakan alfa amilase dan glukoamilase, sedangkan cara hidrolisis asam menggunakan konsentrasi asam optimum dari penelitian Fitriana (2016) yaitu $\mathrm{HCl} 1,0 \mathrm{~N}$. Hasil rendemen gula cair dari hidrolisis enzimatis dan asam dapat dilihat pada Gambar 4.

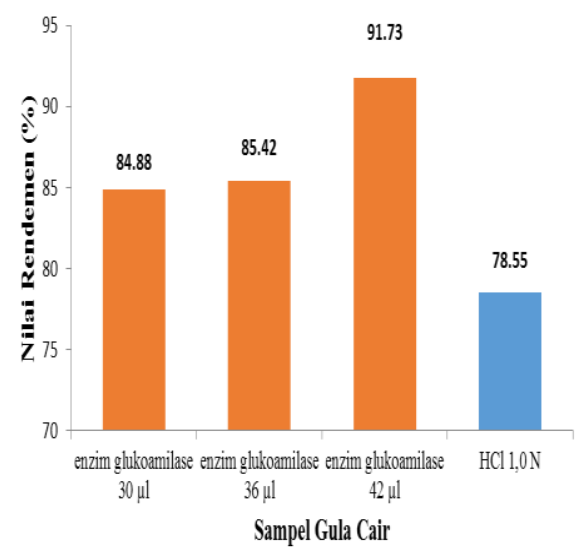

Gambar 4. Rendemen Gula Cair

Rendemen tertinggi hasil hidrolisis pati ubi jalar kuning sebesar 91,73\% pada volume enzim $42 \mu \mathrm{L}$. Rendemen gula cair hasil hidrolisis asam sebesar 78,55 \%. Konsentrasi asam yang dipakai adalah konsentrasi asam optimum dalam pembuatan gula cair pada penelitian Fitriana (2016). Rendemen gula cair yang dihasilkan dari hasil hidrolisis pati jagung manis secara enzimatis, lebih besar bila dibandingkan dengan gula cair hasil hidrolisis pati jagung manis secara asam. Hal ini sesuai dengan pernyataan Risnoyatiningsih (2011), bahwa pembuatan gula cair dengan hidrolisis secara asam menghasilkan rendemen gula yang lebih rendah bila dibandingkan hidrolisis pati secara enzimatis. Pada hidrolisis pati secara enzimatis, enzim bekerja spesifik. Enzim alfa-amilase bekerja memutus ikatan $\alpha$ $(1,4)$ glikosidik dan enzim glukoamilase memecah ikatan $\alpha$ - $(1,4)$ glikosidik dan $\alpha$ $(1,6)$ glikosidik pada pati. Sedangkan pada hidrolisis pati secara asam, pati akan dipecah secara acak (Mahmudatussaadah, 2014). Berdasarkan Gambar 4, semakin besar jumlah enzim yang ditambahkan maka semakin besar jumlah rendemen gula cair yang dihasilkan (Rahmawati et al., 2015). 
Tabel 2. Karakteristik Parameter Fisik Gula Cair

\begin{tabular}{ccccc}
\hline \multirow{2}{*}{ Sampel Gula } & Volume & \multicolumn{3}{c}{ Parameter } \\
\cline { 3 - 5 } & Glukoamilase & Rasa & Bau & Warna \\
\hline \multirow{2}{*}{ Enzim } & $30 \mu \mathrm{L}$ & Manis & Khas & Kuning \\
(alfa amilase 42 $\mu \mathrm{L})$ & $36 \mu \mathrm{L}$ & Manis & Khas & Kuning \\
& $42 \mu \mathrm{L}$ & Manis & Khas & Kuning \\
Asam Klorida 1,0 N & & Manis & Khas & Kuning \\
SNI 01-2978-1992 & & Manis & Tak berbau & Tak berwarna \\
\hline
\end{tabular}

Uji kualitatif pati dilakukan untuk mengetahui adanya kandungan pati dalam sampel gula cair menggunakan larutan lugol. Hasil uji ini dapat dilihat pada Gambar 5.

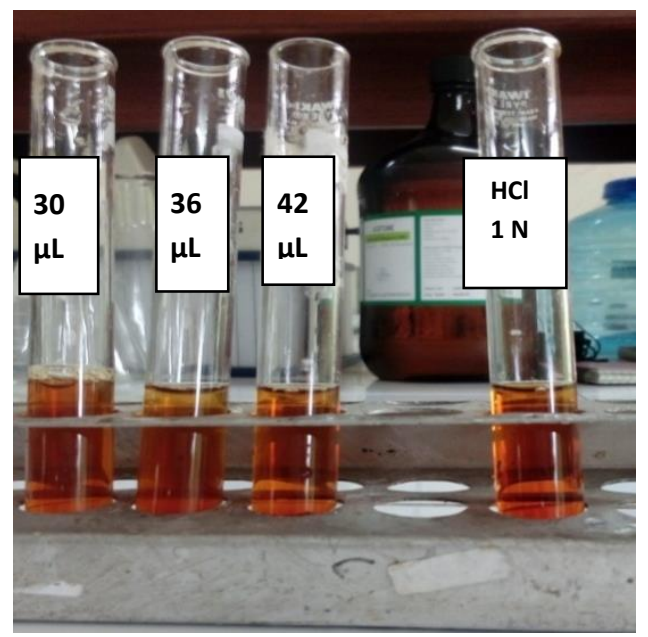

Gambar 5. Uji lugol Gula Cair secara Enzimatis dan Asam

Berdasarkan Gambar 5, hasil negatif diperoleh pada uji kualitatif pati pada gula cair berbahan baku pati jagung manis. Hal ini menunjukkan bahwa semua pati telah terhidrolisis dengan sempurna. Sampel akan menunjukkan hasil positif apabila masih ada pati yang belum terhidrolisis. Hal ini dapat diamati dari perubahan warna yang terjadi, apabila terbentuk warna biru tua atau ungu maka sampel gula cair tersebut positif mengandung pati.

Gula cair hasil hidrolisis enzim optimum dan gula cair hidrolisis asam selanjutnya dilakukan uji kimia yaitu analisis proksimat dan dibandingkan dengan SNI 01-2978-1992. Hasil analisis proksimat gula cair dapat dilihat pada Tabel 3.

Semakin rendah kadar air gula cair, maka kualitas gula cair tersebut semakin baik karena nilai viskositasnya tinggi sehingga gula cair tersebut semakin kental. Selain itu kadar air yang rendah akan mengurangi bahaya pertumbuhan mikroba. Jadi kadar air memegang peranan penting dalam proses pembusukan dan ketengikan. Berdasarkan hasil analisis kadar air gula cair dari kedua perlakuan hidrolisis baik asam maupun enzim kemudian dibandingkan dengan SNI 01-2978-1992 maka kedua jenis gula cair tersebut belum memenuhi syarat keberterimaan. Oleh karena itu, diperlukan metode tertentu untuk menurunkan nilai kadar air yang diperoleh. Proses pengeringan, penambahan gula, dan penambahan garam yang bersifat higroskopis adalah beberapa cara untuk menurunkan nilai aktivitas air (Buckle, 1987). Dalam hal produk yang dihasilkan yaitu gula cair, maka pengeringan merupakan metode yang pas untuk mengurangi kadar air dengan suhu tinggi (penguapan) yang bertujuan untuk mengawetkan bahan. Proses utama yang terjadi selama pengeringan adalah transfer panas dan transfer massa.

Kadar abu gula cair hidrolisis enzimatis hasil penelitian adalah 0,09\% dan kadar abu gula cair hidrolisis asam adalah $1,03 \%$. Peningkatan kadar abu dipengaruhi oleh terlarutnya garam-garam mineral yang terkandung dalam pati sumber gula cair (Yuniarti, 2004). 
Tabel 3. Kandungan Proksimat Gula Cair

\begin{tabular}{lccc}
\hline \multicolumn{1}{c}{ Parameter } & $\begin{array}{c}\text { Gula Cair } \\
\text { Enzim }\end{array}$ & $\begin{array}{c}\text { Gula Cair } \\
\text { Asam }\end{array}$ & Pati Jagung manis \\
\hline Air (\%) & 58,88 & 34,36 & 3,94 \\
Abu (\%) & 0,09 & 1,03 & 1,12 \\
Protein (\%) & 0,31 & 0,75 & 9,46 \\
Lemak (\%) & 0,19 & 0,10 & 1,18 \\
Karbohidrat (\%) & 42,01 & 52,99 & 63,89 \\
\hline
\end{tabular}

Persyaratan SNI 01-2978-1992 untuk kadar abu gula cair adalah maksimal $1 \%$. Kadar abu gula cair hidrolisis asam tidak memenuhi syarat. Nilai kadar abu gula cair secara asam lebih tinggi, dibanding gula cair secara enzimatis karena pada saat dilakukan penetralan gula cair secara asam penambahan $\mathrm{Na}_{2} \mathrm{CO}_{3}$ jauh lebih banyak dibandingkan penambahan pada gula cair secara enzimatis. $\mathrm{Na}_{2} \mathrm{CO}_{3}$ akan bereaksi dengan $\mathrm{HCl}$ membentuk $\mathrm{NaCl}$ yang merupakan garam anorganik yang dapat mempengaruhi kadar abu, sehingga kadar abu dalam gula cair secara asam lebih tinggi dibandingkan secara enzimatis (Saputra, 2015).

Kadar protein pada gula cair secara enzim didapatkan sebesar $0,31 \%$, sedangkan pada gula cair secara asam $0,75 \%$. Kadar protein untuk gula cair belum mempunyai SNI, sehingga nilai kadar protein masih belum bisa dibandingkan dengan standar mutu. Kadar protein kedua gula cair bila dibandingkan dengan kadar protein pati jagung manis lebih kecil.

Kadar lemak pada gula cair secara enzimatis yaitu sebesar 0,186\% dan secara asam yaitu sebesar 0,101 \%. Berdasarkan hasil tersebut, gula cair mengandung lemak yang kecil, sehingga ketika dikonsumsi berlebihan tidak akan membahayakan bagi kesehatan. Selain itu, kandungan lemak yang tinggi tidak menguntungkan dalam penyimpanan gula cair, karena akan menyebabkan ketengikan pada gula cair.

Kadar karbohidrat pada gula cair secara enzimatis diperoleh sebesar 42,01\%, sedangkan secara asam diperoleh sebesar $52,99 \%$. Nilai kadar karbohidrat pada gula cair secara enzim maupun secara asam lebih rendah dibandingkan dengan nilai kadar karbohidrat pada pati jagung manis yaitu sebesar 63,89 \%. Penurunan kadar karbohidrat dapat terjadi karena karbohidrat pada pati jagung manis telah dihidrolisis menjadi gula cair sehingga kandungan karbohidratnya berkurang. Gula dapat dikatakan sebagai salah satu sumber energi, hal ini karena kandungan karbohidrat dalam gula cair termasuk tinggi. Karbohidrat merupakan bagian terpenting dalam bahan pangan. Karbohidrat dapat memengaruhi karakteristik bahan makanan, misalnya warna, rasa, aroma, dan tekstur (Winarno, 2002).

Kandungan energi dalam makanan dapat dihitung dengan rumus $(9 \mathrm{x}$ kadar lemak $)+(4 \times$ kadar protein $)+(4 \times$ kadar karbohidrat). Kandungan energi gula cair hasil hidrolisis enzim sebesar 170,95 kkal/100g sedangkan gula cair hasil hidrolisis asam sebesar 215,77 kkal/100g. Kandungan energi ini mencakup karbohidrat, protein dan lemak yang terdapat dalam gula cair. Perbedaan pada kandungan energi kedua gula cair karena kadar protein, kadar lemak dan kadar karbohidrat yang berbeda pula.

\section{KESIMPULAN}

Rendemen gula cair hasil hidrolisis pati jagung manis secara enzimatis lebih besar dibandingkan dengan rendemen gula cair hasil hidrolisis pati jagung manis secara asam. Rendemen gula cair hasil hidrolisis secara enzimatis tertinggi sebesar 91,73 \% pada volume enzim $42 \mu \mathrm{L}$, sedangkan rendemen gula cair hasil hidrolisis secara asam sebesar 78,55\% pada konsentrasi $\mathrm{HCl} 1,0 \mathrm{~N}$. Gula cair hasil 
hidrolisis secara enzimatis memiliki kualitas yang lebih baik dibandingkan dengan gula cair hasil hidrolisis secara asam dilihat dari parameter kadar air, kadar abu, kadar gula pereduksi dan kandungan energinya.

\section{DAFTAR PUSTAKA}

Arnata, I.W., B.H. Admadi, dan E. Pardede. 2013. Produksi Gula Cair dari Pati Ubi Jalar Melalui Proses Likuifikasi dan Sakarifikasi Secara Enzimatis. Fakultas Teknologi Industri Pertanian. Universitas Udayana. Bali.

Badan Standardisasi Nasional. 1992. SNI 01-2891-1992 Cara Uji Makanan dan Minuman. Jakarta.

Badan Standardisasi Nasional. 1992. SNI 01-2978-1992 Sirup Glukosa. Jakarta.

Badan Standardisasi Nasional. 1995. SNI 01-3727-1995 Tepung Jagung. Jakarta.

Buckle, K.A. 1987. Ilmu Pangan. UI Press. Jakarta.

Devita, C. 2013. Perbandingan Metode Analisis Menggunakan Enzim Amilase dan Asam dalam Pembuatan Sirup Glukosa dari Pati Ubi Jalar Ungu. Skripsi. Fakultas MIPA. Universitas Negeri Semarang.

Fitriana.2016. Variasi Konsentrasi Asam klorida dan Lama Hidrolisis Pati Jagung Manis (Zea mays L.) dalam Pembuatan Gula Cair. Skripsi. Fakultas Matematika dan Ilmu Pengetahuan Alam, Universitas Nusa Bangsa. Bogor

Koswara, S. 2009. Ubi Jalar dan Hasil Olahannya (Teori dan Praktek). Pustaka Sinar Harapan. Jakarta.

Koswara, S. 2013. Pengolahan Ubi Jalar. Departemen Ilmu dan Teknologi Pangan dan Seafast Center IPB. Institut Pertanian Bogor. Bogor.
Laelasari, H. 2016. Hidrolisis Pati Ubi Jalar Putih Menjadi Gula Cair Secara Asam. Skripsi. Program Studi Kimia. Fakultas Matematika dan Ilmu Pengetahuan Alam. Universitas Nusa Bangsa.

Mahmudatussadah, A. dan E. Mulyana. 2013. Optimasi Produksi Gula Cair dari Pati dan Bubur Ubi Jalar Cilembu Secara Enzimatis dengan Teknik Direct Continous Saccharification. Penelitian. Fakultas Pendidikan Teknologi dan Kejuruan. Universitas Pendidikan Indonesia.

Mahmudatussadah, A. 2014. Komposisi Kimia Ubi Jalar (Ipomoea batatas L.) Cilembu pada Berbagai Waktu Simpan sebagai Bahan Baku Gula Cair. Artikel PANGAN Vol. 23 (1): 53-64.

Nugraha, R.A. 2016. http: // swasembada. net/ 2016/03/18/tahun-2016-produksigula-menurun-tahun-2017-impormenggila/. Tahun 2016 Produksi Gula Menurun Tahun 2017 Impor Menggila. Diakses tanggal 13 September 2016.

Nugraha, R.A. $2016 . \quad$ http: // swasembada. net/ 2016/05.11.2016tahun-berat-bagi-industri-gulanasional/. 2016. Tahun Berat Bagi Industri Gula Nasional. Diakses tanggal 13 September 2016.

Rachmawati, A. dan Yunianta. 2015. Hidrolisis Pati Jahe Emprit dengan Enzim Alfa Amilase. Jurnal Pangan dan Agroindustri. Vol 3 (3): 12521262.

Richana, N., P. Lestari, N. Chilmijati, dan S. Widowati. 1999. Karakterisasi Bahan Berpati (Tapioka, Garut, dan Sagu ) dan Pemanfaatannya Menjadi Glukosa Cair. Prosiding. PATPI.

Richana, N. 2006. Gula Singkong Dapat Diproduksi Di Pedesaan. Warta Penelitian dan Pengembangan 
Pertanian. Balai Besar Penelitian Pengembangan Pascapanen Pertanian. Bogor.

Richana, N. dan Suarni. 2008. Teknologi
Pengolahan
Jagung. Warta
Penelitian dan Pengembangan
Pertanian Balai Besar Penelitian
Pengembangan Pascapanen
Pertanian. Bogor.

Risnoyatiningsih, S. 2011. Hidrolisis Pati

Ubi Jalar Kuning Menjadi Glukosa Secara Enzimatis. Jurnal Teknik Kimia. Vol. 5 (2): 417-424.

Triyono, A. 2007. Peningkatan Fungsional Pati dari Ubi Jalar (Ipomea batatas L.) dengan Enzim $\alpha$-Amilase (Bacillus subtilis) sebagai Bahan Subtitusi Pengolahan Pangan. Jurnal Sains MIPA. Vol. 13 (1): 60-66.

Triyono, A. 2009. Komposisi Gula Glukosa dari Hasil Hidrolisis Pati Ubi Jalar (Ipomea batatas, L) dalam Upaya Pemanfaatan Pati Umbi-umbian. Balai Besar Pengembangan Teknologi TepatGuna-LIPI, Subang.

Utiarahman, G. 2014. Karakteristik Kimia dan Organoleptik Nugget Ikan Layang (Decapterus sp.) yang Disubtitusi dengan Tepung Ubi jalar Putih (Ipomea batatas L.). Thesis. Universitas Negeri Gorontalo. 